\title{
Online Design Thinking Problems for Enhancing Motivation of Gifted Students
}

\author{
Ayed H. Ziadat \\ Al-Balqa'a Applied University, Princess Rahma University College, \\ Department of Special education, Al-Salt, Jordan \\ https://orcid.org/0000-0002-7920-2419 \\ Mohammad Abed Sakarneh \\ Al-Balqa'a Applied University, Princess Rahma University College, \\ Department of Special education, Al-Salt, Jordan \\ https://orcid.org/0000-0001-8683-7941
}

\begin{abstract}
Motivation is important for harnessing abilities and competencies, even if students are naturally or potentially gifted. This study used design thinking pedagogy as an innovative approach to motivate students holistically to learn and attend school. Design thinking is an approach to acquire and apply knowledge in a real situation that involves five stages: empathy, define, ideate, prototype, and test. The study was a quantitative quasi-experimental study with a one-group design and pre and post-tests. The study evaluated intrinsic and four extrinsic motivation categories - integrated, identified, introjected, and external regulation - to evaluate gifted students' motivation to do coursework, and used a motivation scale to gauge their willingness to attend school, and an attitude questionnaire to determine students' satisfaction with and engagement in the design thinking class. The experimental group consisted of 77 randomly selected gifted students at the King Abdullah II School for Excellence. After engaging in the design thinking class, the gifted students' scores on all motivation categories were higher in the post-test than they had been in the pre-test. However, gifted students' motivation levels were not associated with their gender, grades, and SAT scores. Thus, the design thinking approach is a promising approach for educating gifted students; students found it satisfying and they exhibited high levels of engagement behavior. The study results recommend that a design thinking approach is worth pursuing to increase gifted students' motivation. The researchers recommend considering both gifted and non-gifted students in future studies involving the design thinking approach.
\end{abstract}

Keywords: design thinking approach; extrinsic motivation; gifted students; motivation; intrinsic motivation 


\section{Introduction}

Achieving the aim of developing 21st century skills and capabilities, namely, creative thinking, critical thinking, communication, and collaboration, requires teachers to adopt a suitable pedagogy to meet students' unique needs in the class (Sakarneh \& Al-Swelmyeen, 2020; Samat \& Ismail, 2020; Stith et al., 2020). Gifted students, specifically, encounter a lack of teaching support in the regular classroom, which causes them to experience more motivational issues in relation to learning and school than their non-gifted peers. These motivational issues have commonly been suggested to be a cause of underachievement (Hornstra et al., 2020). Samat and Ismail (2020) explain, furthermore, that gifted students require specially designed programs that motivate them to participate in acquiring and seeking knowledge development. The motivation of gifted students positively impacts their giftedness development (Barabwd et al., 2017). Burns and Martin (2021) and McCoach and Flake (2018) have the same perception about the role of motivation in harnessing abilities and competencies, even for students who are naturally or potentially gifted. They stated that motivation is the catalyst of giftedness; an adequate motivation level is a necessity for developing giftedness for both naturally and potentially gifted students.

A study in Jordan detected a clear difference between the intrinsic motivation levels of gifted female students, their gifted male peers, and ungifted peers (female and male). Gifted male students did not exhibit a higher level of motivation than their ungifted peers of either gender. Despite gifted female and male students being recruited from the same school for excellence, gifted female students acquired substantially greater benefits than their male counterparts (Heilat et al., 2019). This finding suggests that gifted male students gain fewer benefits from education programs that do not focus on fostering their motivation levels.

This study investigated the design thinking pedagogy, as an innovative approach to motivate students about learning and to attend school, so that teachers can provide gifted students with the expected levels of support, satisfaction, and relatedness. The study intended to contribute to supporting classroom organization and meeting gifted students' needs. Studies have found that the majority of gifted students fail to recognize their abilities (Hebert, 2020; Siegle \& McCoach, 2018). Implementing design thinking in the classroom may contribute to supporting students' recognition of their cognitive abilities and competencies. Personal recognition of their abilities is likely to serve gifted students professionally, socially, and emotionally (Hebert, 2020).

This study focused on harnessing the potential benefits and features of a design thinking approach to enhance and upgrade gifted students' motivation, since motivation plays an important role in students' progress and excellence. The benefits of a design thinking approach can be assessed by measuring the difference between students' motivation levels before and after the implementation of the approach. Furthermore, design thinking, as a new learning experience, can introduce students to a new learning concept, and prepare them for the post-high school stage of learning. 


\subsection{Study Objectives}

The study investigated the application of a design thinking approach as a motivational tool. Thus, the study aims were to determine

- Differences between pre and post-tests of gifted students' motivation to learn and attend school;

- Differences in students' motivation that were attributable to their demographic features (gender, grade, SAT score); and

- Whether students developed positive attitudes to learning by approaching problems with design thinking.

\section{Literature Review}

\subsection{Motivation}

The word motivation is derived from the Latin word meveo, meaning move. A simple dictionary definition of motivation is having a reason to engage, accomplish, or do a particular thing. Motivation carries out a force to act or move to action (McCoach \& Flake, 2018). According to self-determination theory, this means stimulating attitudes, values, and tendencies towards action. According to this theory, there are two motivation categories: intrinsic and extrinsic motivation (Hornstra et al., 2020). Intrinsic motivation is the ingrained, inherent, and innate inclination to engage, seek or participate in challenges to feel satisfaction or enjoyment (Heilat et al., 2019). Extrinsic motivation refers to external stimuli or forces that induce a move to action or to taking action (Hornstra et al., 2020; Fleith, 2016).

External stimulation sources have various origins. The current study identifies four types of extrinsic motivation, namely, integrated, identified, introjected, and external regulation (Ryan \& Deci, 2000). Integrated motivation refers to the internalization of the stimuli to the self, through which the action becomes selfdetermined. Identified motivation is the inclination to act by recognizing the personal significance of an act and accepting the act as personal regulation. Introjected motivation is a controlling incentive to act, such as acting due to a feeling of obligation; in other words, it is about acting in order to avoid guilt or anxiety (e.g., students study because their parents expect them to). External regulation refers to the motivation or stimulus to act to satisfy external demands, or to acquire external rewards through external causality. There is a further motivation category that reflects the concept of lack of intention to act, and personal causation (Ryan \& Deci, 2000).

Motivation and giftedness are interrelated, and motivation is considered a fundamental catalyst for developing giftedness (Burns \& Martin, 2021; Hornstra et al., 2020; Samat \& Ismail, 2020; McCoach \& Flake, 2018; Barabwd et al., 2017). Thus, scholarly interest has turned to investigating the motivation level of gifted students, and comparing it to that of non-gifted students, for example, the Jordanian study of Heilat et al. (2019). Another research interest is the role of motivation and its impact on gifted students' performance and progression. For example, Barabwd et al. (2017) surveyed gifted students' perceptions of the role of motivation in developing giftedness and found that they had highly positive perceptions in this regard, and believed it played a significant role in developing giftedness. In contrast, research studies (e.g., Steenbergen-Hu et al., 2020; Rubenstein et al., 2012) argue that lack of motivation can be a predictor of 
underachievement by gifted students. Burns and Martin (2021) discuss recent research into the motivation of gifted students and suggest practical strategies teachers can apply to foster giftedness development of gifted students. They also provide effective strategies to address motivational issues. This study supports these suggestions and uses a design thinking approach to foster gifted students' motivation.

\subsection{Design Thinking}

Design thinking relates to design theory, which is a philosophy that clarifies concepts and criticizes current models and practices. However, this theory is widely known in industrial settings, and not in the education field (Simeon et al., 2020). In education, design thinking is a teaching approach or environment that can be distinguished from conventional learning approaches for acquiring knowledge, which goes beyond acquiring knowledge, to the implementation and application of knowledge in the real situation. Design thinking is not only applicable to a single discipline, but to multidisciplinary contexts that include engineering, social sciences, medicine, education, and so forth (Tsai \& Wang, 2020; Wrigley et al., 2018; Henriksen et al., 2017). In education, design thinking is considered to be a cognitive process that includes creation, experimentation, feedback, and redesign of whatever the field of the subject comprises ( $\mathrm{Li}$ et al., 2019).

Design thinking is a holistic approach to acquiring and applying knowledge in real situations. It involves five stages: empathy, define, ideate, prototype, and test. Empathy involves learning more about the problem and people involved. Define is about clarifying the problem and setting goals for solving it, as expected. Ideate is about investigating, doing research, and getting ideas to achieve the goals. Prototype is about selecting the best solution and creating prototypes that can be justified. Lastly, in the test stage, the prototype is tested in the real situation and evaluated with experiments (Stith et al., 2020).

Studies investigated the role of a design thinking approach for different aspects or dimensions, such as increasing creative thinking and innovation (Henriksen et al., 2017), self-efficacy (Tsai \& Wang, 2020), and so forth. Simeon et al. (2020) applied an afterschool-program-based design thinking approach in one discipline (physics) and evaluated its potential to increase students' achievement in developing concepts. Statistical results detected an increase in the level of students' achievement, with a difference between genders in favor of male students. Educators had positive perceptions of the utility of a design thinking approach for educating gifted students. Teachers said that design thinking tasks foster the development of 21st century skills, has psychological benefits, and increases the motivation level of students (Stith et al., 2020). Teachers explained that a design thinking approach increases motivation. Firstly, students exhibit active engagement, find the approach exciting and fun, and feel that they are making a contribution to society, because they have the opportunity to develop solutions on their own. The second reason why design thinking increases motivation, according to teachers, is that the task context is authentic and transferable to other contexts. Thirdly, the problems students solve are from the real word, which students experience, feel, see, and live. In the fourth place, 
students are not constrained to particular ways of finding solutions; instead, they can create their own solutions in their own ways (Stith et al., 2020).

A study of design thinking in a subject relating to the human-computer interface assessed students' motivations and found that doing design thinking tasks increased students' motivation to do coursework and attend school. Furthermore, students showed higher levels of self-efficacy and lower test anxiety, and their ability to control, manage, and regulate their effort and time improved. The study linked this increase in motivation to the facilitation of the flow of knowledge in the course (Ahmad et al., 2017). Similar results were obtained by a study that targeted university students, in which more than $80 \%$ of students stated that they had the self-motivation to pursue success in a design thinking course. Students ascribed their perseverance to the significance of these skills for their selfdevelopment, which caused their engagement to become self-determined (Wei et al., 2020). A second study used design thinking methodology to enhance university students' motivation and performance in their graduate projects. Results confirm the significance of a design thinking approach for fostering motivation (Bordel et al., 2019).

In summary, studies found that learning with a design thinking program increased self-motivation of students, and improved teachers' perceptions about design thinking (Wei et al., 2020; Ahmad et al., 2017). However, there is no empirical evidence for this association. Thus, the current study intended to find empirical evidence for this claim and, furthermore, determine students' attitudes toward a design thinking program.

\section{Method}

The study used a quasi-experimental approach with a one-group design and pre and post-tests.

The study examined the effect of design thinking as a learning approach on students' motivation in a multidisciplinary context. The study investigated afterschool activities, because the setting of the school's conventional activities was not conducive to setting design thinking problems. The researchers played a teacher role in the study, as the usual teacher was unqualified to carry out a design thinking approach. Furthermore, for students to engage in design thinking problems, they need to have integrated and resource-rich settings. All students could access various online laboratories and online research databases. The students could also use a university chemistry library or computer facilities under the researchers' guidance.

\subsection{Study Participants and Learning Environments}

The study used online learning management software at the King Abdullah II School for Excellence (Grade 11 to 12 (Tawjihi $\left.{ }^{1}\right)$ ) in Jordan. Seventy-seven students were selected randomly from the secondary grades - 45 female and 32 male students. They provided signed informed consent, and parental approval was obtained. Fifty-two students were in Grade 11, and 25 students were in Grade 12. SAT scores were obtained for all students from their student profiles at the school. The SAT is a foreign test that is taken for three main subjects: reading, writing,

${ }^{1}$ The General Secondary Education Certificate Examination in Jordan and Palestine. 
and mathematics. SAT scores were used, rather than grade point averages, to avoid biasing the results due to school administration or other factors, and to ensure homogeneity. The majority of students $(\mathrm{N}=72)$ obtained average SAT scores in excess of $90 \%$; only five students obtained average scores ranged between $80.4 \%$ and $90 \%$.

Design thinking problems were posed via online learning modules that the school had adopted for learning purposes. The study opted to use the online learning modules because, at the time the study was administered, the school used online learning due to global health circumstances.

\subsection{Procedure}

All students engaged in three weekly multidisciplinary sessions via Microsoft Teams (online platform). Each session was a one-hour class period that was scheduled after the end of the school schedule. These sessions differed from conventional school lessons and involved the authentic discipline of design thinking about a problem. Most students selected tasks from a pool of design thinking problems based on their preferences. Only the first five problems were reported by the study (see Table 1 ).

Each task was discussed in five online sessions. The first session was an introductory session, in which the problem was either stated by a teacher or sparked by trigger questions. In the second session, students presented information that they had collected during searches relating to the problem; students presented their perceptions to their peers. In the third session, students were encouraged to reveal the solutions they suggest for solving the problem, and to explain how they planned to implement the solutions. The fourth session involved the teacher encouraging students to report on their progress and discuss any obstacles they faced, so that they could overcome the obstacles, either by suggestions by group members, or by the teacher's suggestions and guidance. In the fifth session, each group assumed complete responsibility for presenting their solution and a report to their classmates. In conclusion, the solutions were driven and offered by participants and approved by the teacher.

Each problem was solved by students in a group of three gifted students. New groups were formed between design thinking problems. This setting is consistent with a student-centered classroom and student-driven environment.

Table 1. Tasks list of online design thinking problems developed during the study

\begin{tabular}{|c|c|c|}
\hline $\begin{array}{l}\text { Online design } \\
\text { thinking problem }\end{array}$ & Description & Related content \\
\hline $\begin{array}{l}\text { High rate of } \\
\text { consumption of } \\
\text { water for } \\
\text { irrigation } \\
\text { purposes }\end{array}$ & $\begin{array}{l}\text { A graphic presentation of the water } \\
\text { consumption rate by each activity of } \\
\text { daily life, and a classification of grey } \\
\text { and black water. Identifying the best } \\
\text { water sample to reuse for irrigation } \\
\text { according to Jordanian standards for } \\
\text { irrigation water. Build a simple filter to } \\
\text { reuse grey water sample for irrigation. }\end{array}$ & $\begin{array}{l}\text { Chemistry, social } \\
\text { sciences, material } \\
\text { research, life sciences }\end{array}$ \\
\hline $\begin{array}{l}\text { Waste } \\
\text { management }\end{array}$ & $\begin{array}{l}\text { Feasibility study of recent solutions for } \\
\text { waste management mechanisms, }\end{array}$ & $\begin{array}{l}\text { Administration } \\
\text { sciences, engineering, }\end{array}$ \\
\hline
\end{tabular}




\begin{tabular}{|l|l|l|}
\hline & $\begin{array}{l}\text { enabling features that facilitate } \\
\text { management, and a survey of } \\
\text { residents' perceptions. }\end{array}$ & $\begin{array}{l}\text { life sciences, computer } \\
\text { and information } \\
\text { sciences, social } \\
\text { sciences }\end{array}$ \\
\hline $\begin{array}{l}\text { High rate of } \\
\text { dependency on } \\
\text { social media }\end{array}$ & $\begin{array}{l}\text { Suggest application features or } \\
\text { interface to reduce time spent on social } \\
\text { media. }\end{array}$ & $\begin{array}{l}\text { Computer and } \\
\text { information sciences, } \\
\text { social sciences, } \\
\text { psychology }\end{array}$ \\
\hline $\begin{array}{l}\text { Lowering the } \\
\text { unemployment } \\
\text { rate }\end{array}$ & $\begin{array}{l}\text { Study solutions and provide reports } \\
\text { related to other countries that } \\
\text { succeeded in lowering its } \\
\text { unemployment rate; discuss probable } \\
\text { and unlikely solutions. }\end{array}$ & $\begin{array}{l}\text { Life sciences, social } \\
\text { sciences, psychology, } \\
\text { financial sciences, } \\
\text { administrative } \\
\text { sciences }\end{array}$ \\
\hline $\begin{array}{l}\text { Developing } \\
\text { awareness of and } \\
\text { reducing bullying }\end{array}$ & $\begin{array}{l}\text { Design a presentation suggesting ways } \\
\text { to educate communities about bullying } \\
\text { and suggest ways to cope with } \\
\text { bullying. }\end{array}$ & $\begin{array}{l}\text { Life sciences, social } \\
\text { sciences, psychology }\end{array}$ \\
\hline
\end{tabular}

\subsection{Instrument}

A student motivation questionnaire, in English, was used for pre and postassessment. It comprises scales measuring academic motivation (four items) and motivation for school (18 items distributed over four dimensions). All items of both scales are answered on a five-point Likert scale ranging from "totally not applicable to me" to "totally applicable to me". The academic motivation scale consists of four items developed by Vallerand et al. (1992). The motivation for school scale consists of four facets: external regulation, introjected, intrinsic, and identification motivation, and was developed by Rayan and Connell (1989). Both scales have high psychometric properties. The academic motivation scale and motivation for school scale scored above the recommended reliable score (Cronbach's alpha >0.70) (Hornstra et al., 2020; Utvaer \& Haugan, 2016). The psychometric properties of the scale used in the current study also have acceptable validity, according to the Pearson correlation coefficient recorded for the scale, in which all items of the motivation scale correlate with their dimensions, and all statements' correlation values were in excess of 0.31 , which is the lowest acceptable value (Core et al., 2021).

The study used SPSS software to analyze participants' responses, and embedded descriptive and inferential statistics to validate study objectives.

Table 2. Pearson correlation test to show construct validity

\begin{tabular}{|c|c|c|c|c|c|c|c|c|c|}
\hline \multicolumn{2}{|l|}{ Amotivation } & \multicolumn{2}{l|}{ External } & \multicolumn{2}{l|}{ Introjection } & \multicolumn{2}{l|}{ Identification } & \multicolumn{2}{l|}{ Intrinsic } \\
\hline$\#$ & Correlation & $\#$ & Correlation & $\#$ & Correlation & $\#$ & Correlation & $\#$ & Correlation \\
\hline 1 & $.802^{* *}$ & 1 & $.379^{* *}$ & 1 & $.470^{* *}$ & 1 & $.353^{* *}$ & 1 & $.854^{* *}$ \\
\hline 2 & $.860^{* *}$ & 2 & $.565^{* *}$ & 2 & $.539^{* *}$ & 2 & $.528^{* *}$ & 2 & $.770^{* *}$ \\
\hline 3 & $.824^{* *}$ & 3 & $.400^{* *}$ & 3 & $.326^{* *}$ & 3 & $.583^{* *}$ & & \\
\hline 4 & $.863^{* *}$ & 4 & $.494^{* *}$ & 4 & $.373^{* *}$ & 4 & $.409^{* *}$ & & \\
\hline & & 5 & $.323^{* *}$ & 5 & $.225^{*}$ & 5 & $.509^{* *}$ & & \\
\hline & & & & 6 & $.355^{* *}$ & & & & \\
\hline
\end{tabular}


Furthermore, the reliability of the scale is also acceptable, as it recorded a Cronbach's alpha higher than the threshold value $(>0.70)$. See Table 3.

Table 3. Cronbach Alpha Coefficient for motivation scale

\begin{tabular}{|l|c|}
\hline Dimension & Cronbach's alpha \\
\hline Amotivation & 0.856 \\
\hline External & 0.776 \\
\hline Introjection & 0.812 \\
\hline Identification & 0.760 \\
\hline Intrinsic & 0.704 \\
\hline Motivation (Total) & $\mathbf{0 . 8 7 3}$ \\
\hline
\end{tabular}

The second measure the study used is the attitude scale, which was implemented after the completion of the design thinking classes, to assess students' attitudes about the design thinking problem approach. The scale has two dimensions, namely, satisfaction with program (four items, responses evaluated using fivepoint Likert scale, from "strongly disagree" to "strongly agree") and behavioral engagement in the session (five items with a five-point Likert scale ranging from "never" to "always") developed by Nie and Lau (2009). The scale achieved a good reliability score, since Cronbach's alpha was higher than the accepted threshold $(>0.70)$. See Table 4 .

Table 4. Cronbach's alpha coefficient for attitude scale

\begin{tabular}{|l|c|}
\hline Dimension & Cronbach alpha \\
\hline Satisfaction & 0.775 \\
\hline Behavior & 0.741 \\
\hline Attitude (Total) & $\mathbf{0 . 8 3 0}$ \\
\hline
\end{tabular}

\subsection{Normality and Homogeneity Test}

Before starting to test the hypotheses, the researcher made sure that the data followed the normal distribution, by applying a set of special tests. See Table 5 .

Table 5. Normal distribution and homogeneity tests for the study data

\begin{tabular}{|l|c|c|c|c|c|c|}
\hline Kolmogorov-Smirnov & \multirow{2}{*}{ Kurtosis } & \multirow{2}{*}{ Skewness } & \multicolumn{2}{l|}{} \\
\cline { 6 - 7 } Variables & Value & Sig. & & & Tolerance & VIF \\
\hline Amotivation & 0.957 & 0.562 & 0.564 & -0.541 & 0.685 & 2.001 \\
\hline External & 1.567 & 0.264 & 0.318 & -0.214 & 0.432 & 2.684 \\
\hline Introjection & 0.874 & 0.587 & 0.584 & -0.454 & 0.384 & 2.854 \\
\hline Identification & 0.698 & 0.541 & 0.461 & -0.605 & 0.491 & 1.540 \\
\hline Intrinsic & 1.002 & 0.121 & 0.657 & -0.241 & 0.426 & 2.366 \\
\hline Satisfaction & 1.068 & 0.103 & 0.746 & -0.326 & 0.654 & 1.451 \\
\hline Behavior & 0.888 & 0.354 & 0.555 & -0.567 & 0.441 & 2.214 \\
\hline
\end{tabular}

Note: Sig. $=0.05 ; \mathrm{VIF}=10$

It is clear from Table 5 that the statistical significance values on the KolmogorovSmirnov test are in excess of $\alpha \leq 0.05$, and that all the values for skewness are below -1 . Kurtosis is less than 7 , the tolerance values are greater than 0.05 , while the VIF values are below 10. These tests confirm that all values approximate a normal distribution and, thus, allow the use of parametric methods. 


\section{Results}

\subsection{Group Heterogeneity}

To validate the heterogeneity of the participants of the study, inferential statistics, including a T-test, was used, and heterogeneity was validated. According to Table 6 , an independent sample T-test for gender, grade, and SAT score found that motivation and related facets (amotivation, external, introjection, identification, intrinsic) were not significant at the pre-test; $t$-values for gender were 1.448, 0.502, $-1.110,-0.002,0.242,0.845$, for grade were $0.436,0.049,-1.449,1.036,0.768,0.534$, and for SAT score were $0.376,-1.054,-0.221,-1.095,-0.861,-0.860$, respectively). None of these values are significant at the 0.05 level, which indicates the equivalence of all members of the study sample at the time of the pre-test.

Table 6. Independent sample T-test to show the variance between motivation and its dimensions according to gender, grade, and SAT score at the pre-test

\begin{tabular}{|c|c|c|c|c|c|c|}
\hline Motivation facets & Gender & $\mathbf{N}$ & Mean & Std. deviation & $(t)$ & Pvalue \\
\hline \multirow{2}{*}{ Amotivation } & Male & 32 & 2.56 & 0.95 & \multirow[t]{2}{*}{1.448} & \multirow[t]{2}{*}{.152} \\
\hline & Female & 45 & 2.27 & 0.80 & & \\
\hline \multirow{2}{*}{ External } & Male & 32 & 3.61 & 0.32 & \multirow[t]{2}{*}{.502} & \multirow[t]{2}{*}{.617} \\
\hline & Female & 45 & 3.56 & 0.44 & & \\
\hline \multirow{2}{*}{ Introjection } & Male & 32 & 2.74 & 0.36 & \multirow[t]{2}{*}{$-1.110-$} & \multirow[t]{2}{*}{.271} \\
\hline & Female & 45 & 2.84 & 0.36 & & \\
\hline \multirow{2}{*}{ Identification } & Male & 32 & 3.17 & 0.28 & \multirow[t]{2}{*}{$\begin{array}{l}.002- \\
-\end{array}$} & \multirow[t]{2}{*}{.999} \\
\hline & Female & 45 & 3.17 & 0.35 & & \\
\hline \multirow{2}{*}{ Intrinsic } & Male & 32 & 2.11 & 0.64 & \multirow[t]{2}{*}{.242} & \multirow[t]{2}{*}{.809} \\
\hline & Female & 45 & 2.08 & 0.50 & & \\
\hline \multirow{3}{*}{\begin{tabular}{|l|}
$\begin{array}{l}\text { Motivation } \\
\text { (total) }\end{array}$ \\
\end{tabular}} & Male & 32 & 2.95 & 0.21 & \multirow{2}{*}{.845} & \multirow{2}{*}{.401} \\
\hline & Female & 45 & 2.91 & 0.21 & & \\
\hline & Grade & $\mathbf{N}$ & Mean & Std. deviation & $(\mathrm{t})$ & P value \\
\hline \multirow{2}{*}{ Amotivation } & 11 & 52 & 2.42 & 0.88 & \multirow[t]{2}{*}{.436} & \multirow[t]{2}{*}{.664} \\
\hline & 12 & 25 & 2.33 & 0.88 & & \\
\hline \multirow{2}{*}{ External } & 11 & 52 & 3.58 & 0.41 & \multirow[t]{2}{*}{.049} & \multirow[t]{2}{*}{.961} \\
\hline & 12 & 25 & 3.58 & 0.38 & & \\
\hline \multirow{2}{*}{ Introjection } & 11 & 52 & 2.76 & 0.38 & \multirow[t]{2}{*}{-1.499- } & \multirow[t]{2}{*}{.138} \\
\hline & 12 & 25 & 2.89 & 0.31 & & \\
\hline \multirow{2}{*}{ Identification } & 11 & 52 & 3.12 & 0.32 & 1.036 & .245 \\
\hline & 12 & 25 & 3.16 & 0.31 & & \\
\hline Intrinci & 11 & 52 & 2.13 & 0.55 & .768 & .445 \\
\hline |intrinsic & 12 & 25 & 2.02 & 0.59 & & \\
\hline Motivation & 11 & 52 & 2.93 & 0.21 & 534 & 595 \\
\hline (total) & 12 & 25 & 2.90 & 0.22 & .534 & .59b \\
\hline & $\begin{array}{l}\text { SAT } \\
\text { score }\end{array}$ & $\mathbf{N}$ & Mean & Std. deviation & $(t)$ & P value \\
\hline Amativation & $>90$ & 72 & 2.40 & 0.86 & .376 & .708 \\
\hline Amotivation & $>80.2$ & 5 & 2.25 & 1.15 & & \\
\hline$\Gamma_{1}$ & $>90$ & 72 & 3.57 & 0.40 & $-1.054-$ & .295 \\
\hline External & $>80.2$ & 5 & 3.76 & 0.30 & & \\
\hline Intriection & $>90$ & 72 & 2.80 & 0.36 & $-.221-$ & .826 \\
\hline (11010) & $>80.2$ & 5 & 2.83 & 0.39 & & \\
\hline & $>90$ & 72 & 3.16 & 0.32 & $-1.095-$ & .277 \\
\hline Identification & $>80.2$ & 5 & 3.32 & 0.33 & & \\
\hline
\end{tabular}




\begin{tabular}{|l|c|c|c|c|c|c|}
\hline \multirow{2}{*}{ Intrinsic } & $>90$ & 72 & 2.08 & 0.55 & \multirow{2}{*}{$-.861-$} & \multirow{2}{*}{.392} \\
\cline { 2 - 5 } & $>80.2$ & 5 & 2.30 & 0.67 & & \\
\hline \multirow{2}{*}{$\begin{array}{l}\text { Motivation } \\
\text { (total) }\end{array}$} & $>90$ & 72 & 2.92 & 0.21 & \multirow{2}{*}{$-.860-$} & \multirow{2}{*}{.393} \\
\cline { 2 - 5 } & $>80.2$ & 5 & 3.00 & 0.16 & & \\
\hline
\end{tabular}

\subsection{Descriptive Statistics}

According to the descriptive analysis results, the students had a higher average mean ( $M=4.04$; very high motivation level) on the motivation scale in the post-test than in the pre-test (M=2.92; medium motivation level). In the pre-test, students' scores indicated a medium level of motivation: external regulation and identification motivation levels were high and other motivation categories were medium. The statistical data of the post-test measurement show a tangible difference from the pre-test results for almost all the motivation categories.

Table 7. Mean and standard deviation for (pre and post) motivation and its dimensions

\begin{tabular}{|c|c|c|c|c|}
\hline \multirow[b]{2}{*}{ Dimensions } & \multicolumn{2}{|c|}{ Pre-test } & \multicolumn{2}{|c|}{ Post-test } \\
\hline & Mean & $\begin{array}{c}\text { Std. } \\
\text { Deviation }\end{array}$ & Mean & $\begin{array}{c}\text { Std. } \\
\text { Deviation }\end{array}$ \\
\hline $\begin{array}{l}\text { Honestly, I don't know; I really feel that I am wasting } \\
\text { my time in school }\end{array}$ & 2.34 & 1.07 & 4.03 & 0.73 \\
\hline $\begin{array}{l}\text { I once had good reasons for going to school; } \\
\text { however, now I wonder whether I should continue }\end{array}$ & 2.49 & 1.13 & 4.03 & 0.69 \\
\hline $\begin{array}{l}\text { I can't see why I go to school and frankly, I couldn't } \\
\text { care less }\end{array}$ & 2.51 & 0.93 & 3.83 & 0.64 \\
\hline $\begin{array}{l}\text { I don't know; I can't understand what I am doing in } \\
\text { school }\end{array}$ & 2.23 & 1.04 & 4.10 & 0.66 \\
\hline Amotivation & 2.39 & 0.87 & 4.00 & 0.38 \\
\hline Because I'll get in trouble if I don't & 3.66 & 1.02 & 4.25 & 0.65 \\
\hline Because that's what I'm supposed to do & 3.69 & 0.92 & 4.05 & 0.76 \\
\hline So that the teacher won't yell at me & 3.40 & 0.63 & 3.75 & 0.67 \\
\hline Because that's the rule & 3.45 & 1.08 & 4.13 & 0.66 \\
\hline So others won't get mad at me & 3.69 & 0.89 & 3.79 & 1.06 \\
\hline External regulation & 3.58 & 0.40 & 3.99 & 0.42 \\
\hline $\begin{array}{l}\text { Because I want the teacher to think I'm a good } \\
\text { student }\end{array}$ & 2.70 & 1.06 & 4.29 & 0.48 \\
\hline Because I will feel bad about myself if I don't & 2.70 & 1.08 & 4.27 & 0.62 \\
\hline Because I'll feel ashamed of myself if I don't & 3.23 & 0.71 & 4.38 & 0.49 \\
\hline Because I want the other students to think I'm smart & 2.74 & 1.04 & 4.13 & 0.78 \\
\hline Because it bothers me when I don't & 2.01 & 0.92 & 3.68 & 0.66 \\
\hline Because I want people to like me & 3.40 & 0.71 & 4.53 & 0.50 \\
\hline Introjection & 2.80 & 0.36 & 4.22 & 0.25 \\
\hline Because I want to understand the subject & 3.55 & 0.64 & 4.62 & 0.49 \\
\hline Because 1 want to learn new things & 3.53 & 0.66 & 4.62 & 0.49 \\
\hline To find out if I'm right or wrong & 3.45 & 0.70 & 4.57 & 0.50 \\
\hline $\begin{array}{l}\text { Because I think it is important to work on my } \\
\text { schoolwork }\end{array}$ & 3.31 & 0.80 & 4.52 & 0.50 \\
\hline $\begin{array}{l}\text { Because I wouldn't want (like) to do that (negative } \\
\text { behavior) }\end{array}$ & 2.00 & 0.74 & 1.42 & 0.64 \\
\hline Identification & 3.17 & 0.32 & 3.95 & 0.26 \\
\hline I1: Because it's fun & 2.14 & 0.76 & 3.90 & 0.77 \\
\hline I2: Because I enjoy it & 2.04 & 0.62 & 3.95 & 0.67 \\
\hline
\end{tabular}




\begin{tabular}{|l|l|l|l|l|}
\hline Intrinsic & 2.09 & 0.56 & 3.92 & 0.60 \\
\hline Motivation (total) & 2.92 & 0.21 & 4.04 & 0.16 \\
\hline
\end{tabular}

\subsection{Difference in Motivation Between Pre and Post-tests}

The study examined if there was a difference between the motivation, measured by pre and post-test scores, of gifted students. The descriptive data of the pre and post-tests indicate a clear difference. Foremost, statistically significant differences have to be tested in order to validate differences statistically. Therefore, a paired sample T-test was applied to determine the statistically significant differences between the pre and post-test on motivation (see Table 8).

Table 8. Difference between (pre and post) motivation levels (paired sample T-test) $(\mathrm{N}=77)$

\begin{tabular}{|c|c|c|c|c|c|}
\hline & Mean & $\begin{array}{c}\text { Std. } \\
\text { deviation }\end{array}$ & $\begin{array}{c}\text { Paired } \\
\text { differences }\end{array}$ & $(t)$ & P value \\
\hline Amotivation pre & 2.39 & 0.87 & \multirow{2}{*}{-1.60} & \multirow{2}{*}{$-13.374-$} & \multirow{2}{*}{$0.00^{*}$} \\
\hline Amotivation post & 4.00 & 0.38 & & & \\
\hline External pre & 3.58 & 0.40 & \multirow{2}{*}{-0.42} & \multirow{2}{*}{$-5.845-$} & \multirow{2}{*}{$0.00^{*}$} \\
\hline External post & 3.99 & 0.42 & & & \\
\hline Introjection pre & 2.80 & 0.36 & \multirow{2}{*}{-1.42} & \multirow{2}{*}{$-29.693-$} & \multirow{2}{*}{$0.00^{*}$} \\
\hline Introjection post & 4.22 & 0.25 & & & \\
\hline Identification pre & 3.17 & 0.32 & \multirow{2}{*}{-0.78} & \multirow{2}{*}{$-28.996-$} & \multirow{2}{*}{$0.00^{*}$} \\
\hline Identification post & 3.95 & 0.26 & & & \\
\hline Intrinsic pre & 2.09 & 0.56 & \multirow{2}{*}{-1.83} & \multirow{2}{*}{-19.009} & \multirow{2}{*}{$0.00^{*}$} \\
\hline Intrinsic post & 3.92 & 0.60 & & & \\
\hline Motivation pre total & 2.92 & 0.21 & \multirow{2}{*}{-1.12} & \multirow{2}{*}{$-38.000-$} & \multirow{2}{*}{$0.00^{*}$} \\
\hline Motivation post total & 4.04 & 0.16 & & & \\
\hline
\end{tabular}

The results of the paired sample T-test in Table 8 indicate that there are statistically significant differences in the results of the pre and post-tests for motivation and its related dimensions (amotivation, external, introjection, identification, intrinsic). The paired differences for these dimensions and total degree were -1.60, $-0.42,-1.42,-0.78,-1.73,-1.12$ respectively, and, with the significance level less than $(>0.01)$, the differences were in favor of the post-test, which illustrates the high level of the mean values in that measurement.

\subsection{Attributing Differences in Motivation to Demographic Differences}

The study assessed whether gender, grade, or SAT score had an effect on the motivation level of students after they had attended a design thinking class. The study applied an independent sample T-test; the results are given in Table 9.

Table 9. Independent sample T-test to determine variance between motivation and its dimensions according to gender, grade, and SAT score at the post-test

\begin{tabular}{|c|c|c|c|c|c|c|}
\hline & Gender & $\mathbf{N}$ & Mean & $\begin{array}{c}\text { Std. } \\
\text { deviation }\end{array}$ & $(t)$ & P value \\
\hline \multirow{2}{*}{ Amotivation } & Male & 32 & 3.97 & 0.37 & \multirow{2}{*}{$-.547-$} & \multirow{2}{*}{.586} \\
\hline & Female & 45 & 4.02 & 0.39 & & \\
\hline \multirow{2}{*}{ External } & Male & 32 & 3.99 & 0.39 & \multirow{2}{*}{$-.128-$} & \multirow{2}{*}{.898} \\
\hline & Female & 45 & 4.00 & 0.45 & & \\
\hline \multirow{2}{*}{ Introjection } & Male & 32 & 4.25 & 0.26 & \multirow{2}{*}{.841} & \multirow{2}{*}{.403} \\
\hline & Female & 45 & 4.20 & 0.25 & & \\
\hline
\end{tabular}




\begin{tabular}{|c|c|c|c|c|c|c|}
\hline \multirow{2}{*}{ Identification } & Male & 32 & 3.94 & 0.26 & \multirow{2}{*}{$-.378-$} & \multirow{2}{*}{.706} \\
\hline & Female & 45 & 3.96 & 0.26 & & \\
\hline \multirow{2}{*}{ Intrinsic } & Male & 32 & 3.98 & 0.55 & \multirow{2}{*}{.771} & \multirow{2}{*}{.443} \\
\hline & Female & 45 & 3.88 & 0.63 & & \\
\hline \multirow{3}{*}{$\begin{array}{l}\text { Motivation } \\
\text { (total) }\end{array}$} & Male & 32 & 4.04 & 0.17 & \multirow{2}{*}{.101} & \multirow{2}{*}{.920} \\
\hline & Female & 45 & 4.04 & 0.16 & & \\
\hline & Grade & $\mathbf{N}$ & Mean & $\begin{array}{c}\text { Std. } \\
\text { deviation }\end{array}$ & (t) & $P$ value \\
\hline \multirow{2}{*}{ Amotivation } & 11 & 52 & 3.97 & 0.41 & \multirow[t]{2}{*}{$-.857-$} & \multirow[t]{2}{*}{.394} \\
\hline & 12 & 25 & 4.05 & 0.30 & & \\
\hline \multirow{2}{*}{ External } & 11 & 52 & 3.98 & 0.43 & \multirow[t]{2}{*}{$-.421-$} & \multirow[t]{2}{*}{.675} \\
\hline & 12 & 25 & 4.02 & 0.40 & & \\
\hline \multirow{2}{*}{ Introjection } & 11 & 52 & 4.21 & 0.23 & \multirow[t]{2}{*}{$-.288-$} & \multirow[t]{2}{*}{.774} \\
\hline & 12 & 25 & 4.23 & 0.31 & & \\
\hline \multirow{2}{*}{ Identification } & 11 & 52 & 3.96 & 0.25 & \multirow[t]{2}{*}{.346} & \multirow[t]{2}{*}{.730} \\
\hline & 12 & 25 & 3.94 & 0.28 & & \\
\hline \multirow{2}{*}{ Intrinsic } & 11 & 52 & 3.92 & 0.60 & \multirow[t]{2}{*}{.021} & \multirow[t]{2}{*}{.983} \\
\hline & 12 & 25 & 3.92 & 0.61 & & \\
\hline \multirow{3}{*}{\begin{tabular}{|l|}
$\begin{array}{l}\text { Motivation } \\
\text { (total) }\end{array}$ \\
\end{tabular}} & 11 & 52 & 4.03 & 0.17 & \multirow{2}{*}{$-.512-$} & \multirow{2}{*}{.610} \\
\hline & 12 & 25 & 4.05 & 0.16 & & \\
\hline & Sat score & $\mathbf{N}$ & Mean & $\begin{array}{c}\text { Std. } \\
\text { deviation }\end{array}$ & (t) & P value \\
\hline \multirow{2}{*}{ Amotivation } & $>90$ & 72 & 3.98 & 0.38 & \multirow{2}{*}{$-1.567-$} & \multirow{2}{*}{.121} \\
\hline & $>80.2$ & 5 & 4.25 & 0.25 & & \\
\hline & $>90$ & 72 & 4.01 & 0.43 & 852 & 397 \\
\hline External & $>80.2$ & 5 & 3.84 & 0.26 & .852 & .397 \\
\hline Introiection & $>90$ & 72 & 4.21 & 0.25 & 1303 & 243 \\
\hline Aitiojection & $>80.2$ & 5 & 4.37 & 0.32 & 1.000 & . 243 \\
\hline Identification & $>90$ & 72 & 3.96 & 0.26 & -1068 & 341 \\
\hline Hemtincationti & $>80.2$ & 5 & 3.88 & 0.18 & $-1.000^{-}$ & . \\
\hline Intrimpis & $>90$ & 72 & 3.94 & 0.60 & 860 & 202 \\
\hline intrinsic & $>80.2$ & 5 & 3.70 & 0.57 & .000 & . 393 \\
\hline Motivation & $>90$ & 72 & 4.04 & 0.17 & 200 & 026 \\
\hline (total) & $>80.2$ & 5 & 4.05 & 0.04 & $-.220-$ & .826 \\
\hline
\end{tabular}

The result of the independent sample T-test for the association of motivation with gender, grade, and SAT score indicates that motivation and its dimensions (amotivation, external, introjection, identification and intrinsic with total score) were not significant at post-test $(\mathrm{t})$ values: $-0.547,-0.128,0.841,-0.378,0.771,0.101$, $-0.857,-0.421,-0.288,0.346,0.021,-0.512,-1.567,0.852,1.303,-1.068,0.860,-0.220$ respectively. None of these values are significant at the level of 0.05 , which indicates that there were no statistically significant differences in motivation in relation to gender, grade and SAT score.

\subsection{Gifted Students' Attitudes to the Design Thinking Problem Class}

To determine gifted students' perceptions of and attitudes toward the design thinking approach, all participants completed an attitude questionnaire to rate their satisfaction and engagement behavior. The descriptive statistics of their responses is presented in Table 10. 
Table 10. Attitudes of gifted students towards design thinking $(N=77)$

\begin{tabular}{|l|c|c|}
\hline Attitudes & Mean & Std. deviation \\
\hline I am glad to be in this program & 4.26 & 0.73 \\
\hline I think it is nice to participate and study in this program & 3.94 & 0.73 \\
\hline $\begin{array}{l}\text { If I could, I would rather back to conventional study } \\
\text { settings }\end{array}$ & 2.49 & 0.60 \\
\hline $\begin{array}{l}\text { If I had to move to another settings, I would still want } \\
\text { to study through such setting }\end{array}$ & 4.43 & 0.57 \\
\hline Satisfaction & 3.78 & 0.32 \\
\hline I pay attention well & 4.30 & 0.74 \\
\hline $\begin{array}{l}\text { I keep my attention on the work during the entire } \\
\text { lesson }\end{array}$ & 4.42 & 0.68 \\
\hline I listen carefully when the teacher explains something & 4.27 & 0.74 \\
\hline I try my best to complete class work & 4.44 & 0.68 \\
\hline I try my best to answer the teacher's questions & 4.42 & 0.69 \\
\hline Engagement behavior & 4.37 & 0.27 \\
\hline Attitude (total) & 4.11 & 0.21 \\
\hline
\end{tabular}

The descriptive statistics indicate that students' satisfaction was high, with a total mean of 3.78 and standard deviation of 0.57 . The statement with the highest score (If I had to move to another settings, I would still want to study through such setting) has a mean of 4.43 and standard deviation of 0.57 , which is high. The statement which stipulated (If I could, I would rather back to conventional study settings.

The result for engagement behavior is at a high level, with a mean of 4.37 and a standard deviation of 0.21 . The statement, I try my best to complete class work, ranked first, with a mean of 4.44 and a standard deviation of 0.6 ; it is at a high level. In contrast, the statement, I listen carefully when the teacher explains something, ranked last, with a mean of 4.27 and a standard deviation of 0.74 - which is still at a high level. Total attitude obtained a mean of 4.11, with a standard deviation of 0.21 , which is at a high level.

\section{Discussion}

Descriptive statistics indicate that gifted students attend school because they are forced to do so by external regulations: they wish to avoid getting into trouble, or to avoid punishment, and they obey school regulations. Other factors that stimulated students to attend school were self-identified stimuli, such as the desire to acquire knowledge, and recognizing that attending would help them meet their needs in the future Not surprisingly, gifted students who participated in the study exhibited a medium level of association between academic motivation and their level of external regulation motivation. This indicates that, if students are not obligated to attend school, they will not do so. Their unwillingness may be attributed to the absence of fun and enjoyable activities (thus, an absence of high intrinsic motivation). This finding confirms the study by Heilat et al. (2019), which found that gifted students in Jordan have the same level of motivation as non-gifted students, which hinders gifted students' giftedness development.

The statistical inferential tests validated the significant differences found for all motivation categories levels, in favor of the post-test measurement. It is clear that 
the online design thinking problems played a significant role in fostering the motivation levels of gifted students. This confirms the research results of Stith et al. (2020), Wei et al. (2020), Bordel et al. (2019) and Ahmad et al. (2017). Gifted students found the design thinking class fun and enjoyable. They were stimulated by attending the class and the learning they underwent, and their participation was self-determined (see Table 5), probably because the design thinking class gave students opportunities to develop solutions on their own (Stith, et al., 2020). These opportunities were turned into self-determined participation and fostered a feeling of belonging in relation to the subject, since students dealt with real-life situations - some students lived with these problems (Wei et al., 2020). Furthermore, introjected motivation increased through the design thinking class - students became more interested in external appreciation and pursuing a good image in the eyes of their peers or teachers (see Table 5). This finding resonates in their high satisfaction with the design thinking approach, and their engagement behavior. Their responses indicate that they shared an interest in and were committed to solving the design thinking problems they discussed in class (see Table 10).

Moreover, the design thinking problems presented to students in this study were appropriate for all gifted students (female and male, Grades 11 and 12, and any SAT score band). No differences were found between motivation levels and gender, class, or SAT score categories of gifted students. This was expected, since the participants chose their preferred problem from a pool of suggested real-life problems.

\section{Conclusion}

Motivation plays a significant role in harnessing students' abilities and competencies, even if students are naturally or potentially gifted. The study used design thinking pedagogy as an innovative approach to motivating students to learn and attend school. Design thinking is a holistic approach to acquiring knowledge and applying this knowledge in real situations through five stages: empathy, define, ideate, prototype, and test. The study was a quantitative quasiexperimental study with a one-group design and pre and post-tests. The study evaluated intrinsic and four extrinsic motivation categories, namely integrated, identified, introjected, and external regulation, to evaluate gifted students' motivation to do coursework. A motivation scale was used to gauge their motivation to attend school, and an attitude questionnaire explored students' satisfaction and engagement with the design thinking class. The experimental group consisted of 77 randomly selected gifted students at the King Abdullah II School for Excellence. After engaging in the design thinking class, the students achieved higher scores than in the pre-test for all motivation categories. Furthermore, the students did not exhibit any differences in their post-test motivation levels in relation to gender, grade, and SAT scores. Thus, the design thinking approach is a promising approach for motivating gifted students; the students found it satisfying and high engagement behavior was recorded.

The study design and results justify pursuing implementing a design thinking approach to increase gifted students' motivation for different subjects and at different grade levels. Furthermore, the study did not attempt to find differences 
between gifted and non-gifted students, since gifted students who were enrolled in a school for excellence were engaged in various authentic learning environments, which hindered attempts to distinguish the effect of design thinking on motivation between two groups, as the two groups were engaged in different activities. Thus, the study was limited to one group pre and post-test, and future studies are encouraged to involve two groups, to validate the current results. The researchers recommend involving both gifted and non-gifted students in future studies that use the design thinking approach, which would enable comparisons between the two groups of students. Furthermore, longitudinal studies are recommended, to track the giftedness development of gifted students using a design thinking approach to learning.

\section{References}

Ahmad, W. F., Sarlan, A., Rokhmah, S., \& Ahmad, R. (2017). Integrating design thinking approach to increase student's motivation. 7th World Engineering Education Forum (WEEF) (pp. 268-272). IEEE. https:// doi.org/10.1109/weef.2017.8467148

Barabwd, H., Nor, M., \& Ishak, N. (2017). Gifted students' motivation and its impact on the development of their giftedness. Journal of Education in Black Sea Region, 3(1). https://doi.org/10.31578/jebs.v3i1.118

Bordel, B., Alcarria, R., Manso, M., \& Robles, T. (2019). Enhancing students' motivation and academic results in the context of final projects through design-thinking methodologies. 23th International Technology, Education and Development Conference. INTED2019 Proceedings (pp. 8235-8239). IATED.

Burns, E., \& Martin, A. (2021). Motivational issues in gifted education: understanding the role of students' attribution and control beliefs, self-worth protection and growth orientation. In S. R. Smith (Ed.), Handbook of giftedness and talent development in the Asia-Pacific (pp. 339-357). Springer. https://doi.org/10.1007/978-981-13-30414_15

Core, R., Waring, M., Hedges, L., \& Ashley, L. (2021). Research methods and methodologies in education (3rd ed.). SAGA.

Fleith, D. de S. (2016). Creativity, motivation to learn, family environment, and giftedness: A comparative study. Psicologia: Teoria e Pesquisa, 32, 1-9. https://doi.org/10.1590/0102-3772e32ne211

Hebert, T. (2020). Understanding the social and emotional lives of gifted students. Sourcebooks.

Heilat, M. Q., Seifert, T., \& Qian, M. (2019). Mental motivation, intrinsic motivation and their relationship with emotional support sources among gifted and non-gifted Jordanian adolescents. Cogent Psychology, 6(1), 1-13. https:// doi.org/10.1080/23311908.2019.1587131

Henriksen, D., Richardson, C., \& Mehta, R. (2017). Design thinking: A creative approach to educational problems of practice. Thinking Skills and Creativity, 26, 140-153. https:// doi.org/10.1016/j.tsc.2017.10.001

Hornstra, L., Bakx, A., Mathijssen, S., \& Denissene, J. A. (2020). Motivating gifted and nongifted students in regular primary schools: A self-determination perspective. Learning and Individual Differences, 80, 1-13. https://doi.org/10.1016/j.lindif.2020.101871

Li, Y., Schoenfeld, A. H., diSessa, A. A., Graesser, A. C., Benson, L. C., English, L. D., \& Duschl, R. A. (2019). Design and design thinking in STEM education. Journal for STEM Education Research, 2, 93-104. https://doi.org/10.1007/s41979-019-00020-z 
McCoach, D. B., \& Flake, J. K. (2018). The role of motivation. In S. I. Pfeiffer, E. ShaunessyDedrick, \& M. Foley-Nicpon (Eds.), APA handbook of giftedness and talent (pp. 201213). American Psychological Association. https://doi.org/10.1037/0000038-013

Nie, Y., \& Lau, S. (2009). Complementary roles of care and behavioral control in classroom management: The self-determination theory perspective. Contemporary Educational Psychology, 34(3), 185-194. https://doi.org/10.1016/j.cedpsych.2009.03.001

Rayan, R. M., \& Connell, J. P. (1989). Percevied locus of causality and internalization: Examining reasons for acting in two domains. Journal of Personality and Scial Psychology, 57(5), 749-761. http:// doi.org/10.1037/0022-3514.57.5.749

Rubenstein, L., Siegle, D., Reis, S., Mccoach, D. B., \& Burton, M. (2012). A Complex quest: The development and research of underachievement interventions for gifted students. Psychology in the Schools, 49(7), 678-694. https://doi.org/10.1002/ pits.21620

Ryan, R., \& Deci, E. (2000). Intrinsic and extrinsic motivations: Classic definitions and new directions. Contemporary Educational Psychology, 25(1), 54-67. https://doi.org/10.1006/ceps.1999.1020

Sakarneh, M. A., \& Al-Swelmyeen, M. B. (2020). The extent to which the Jordanian inclusive basic school teachers use the constructivism theory in teaching. Journal of Educational and Social Research, 10(1), 182-197. https://doi.org/10.36941/jesr2020-0017

Samat, F., \& Ismail, E. S. (2020). Meeting the needs of Malaysian mathematically talented students by an enrichment program: A module for primary school students. Madrosatuna: Journal of IslamicElementary School, 4(1), 23-25. https://doi.org/10.21070/madrosatuna.v4i1.55

Siegle, D., \& McCoach, B. (2018). Underachievement and the gifted child. In S. Pfeiffer, E. Shaunessy-Dedrick, \& M. Foley-Nicpon, APA handbook of giftedness and talent (pp. 445-473). American Psychological Association.

Simeon, M. I., Samsudin, M. A., \& Yakob, N. (2020). Effect of design thinking approach on students' achievement in some selected physics concepts in the context of STEM learning. International Journal of Technology and Design Education. https://doi.org/10.1007/s10798-020-09601-1

Steenbergen-Hu, S., Olszewski-Kubilius, P., \& Calvert, E. (2020). The effectiveness of current interventions to reverse the underachievement of gifted students: Findings of a meta-analysis and systematic review. Gifted Child Quarterly, 64(2), 132-165. https://doi.org/10.1177\%2F0016986220908601

Stith, K. M., Potts, M. L., Rubenstein, L. D., Shively, K. L., \& Spoon, R. (2020). Perceptions of K-12 teachers on the cognitive, affective, and conative functionalities of gifted students engaged in design thinking. Journal of STEM Teacher Education, 55(1), 4157. https://doi.org/10.30707/J

Tsai, M.-J., \& Wang, C.-Y. (2020). Assessing young students' design thinking disposition and its relationship with computer programming self-efficacy. Journal of Educational Computing Research, 59(3), 410-428. https://doi.org/10.1177/0735633120967326

Utvaer, B. K., \& Haugan, G. (2016). The academic motivation scale: Dimensionality, reliability, and construct validity among vocational students. Nordic Journal of Vocational Education and Training, 6(2), 17-45. https://doi.org/10.3384/njvet.2242458x.166217

Vallerand, R., Pelletier, L., Blais, M., Briere, N., Senecal, C., \& Vallieres, E. (1992). The academic motivation scale: A measure of intrinsic, extrinsic, and amotivation in 
education. Educational and Psychological Measurement, 52, 1003-1017. https://doi.org/10.1177/0013164492052004025

Wei, L. C., Shamsuddin, W. N., Rozee, I. M., \& Vesudevan, M. (2020). Degree students' self-motivation toward design thinking project. International Journal of Education and Pedagogy,

2(4),

185-192.

http://myjms.mohe.gov.my/index.php/ijeap/article/view/11606

Wrigley, C., Mosely, G., \& Tomitsch, M. (2018). Design thinking education: A comparison of massive open online courses. She Ji: The Journal of Design, Economics, and Innovation, 4(3), 275-292. https:// doi.org/10.1016/j.sheji.2018.06.002 